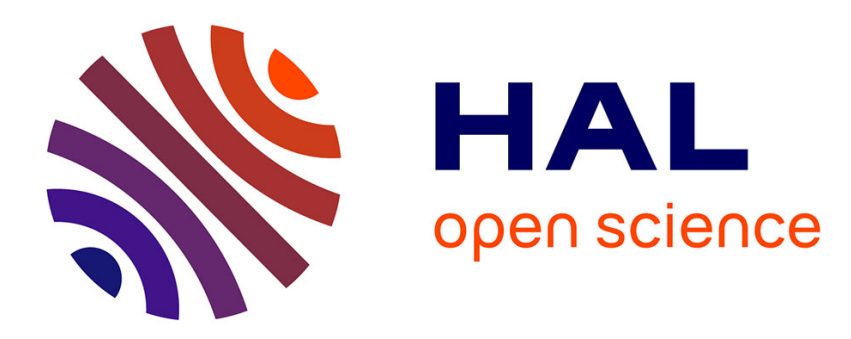

\title{
Ecological factors influencing the transfer of plasmids in vitro and in vivo
}

Denis E. Corpet

\section{To cite this version:}

Denis E. Corpet. Ecological factors influencing the transfer of plasmids in vitro and in vivo. Journal of Antimicrobial Chemotherapy, 1986, 18 (Suppl. C), pp.127-132. hal-00430677

\section{HAL Id: hal-00430677 https://hal.science/hal-00430677}

Submitted on 9 Nov 2009

HAL is a multi-disciplinary open access archive for the deposit and dissemination of scientific research documents, whether they are published or not. The documents may come from teaching and research institutions in France or abroad, or from public or private research centers.
L'archive ouverte pluridisciplinaire HAL, est destinée au dépôt et à la diffusion de documents scientifiques de niveau recherche, publiés ou non, émanant des établissements d'enseignement et de recherche français ou étrangers, des laboratoires publics ou privés. 


\title{
Ecological factors influencing the transfer of plasmids in vitro and in vivo
}

\author{
D. E. Corpet \\ Laboratoire de Recherche sur les Additifs Alimentaires, \\ Institut National de la Recherche Agronomique, B.P.3, 31931 Toulouse, France
}

\begin{abstract}
Plasmid transfer in the gut depends on the concentrations of recipient and donor bacteria and on their fertility. The main determining factors for the former are flow rate, concentration of limiting substrate, growth rates, adhesion, contamination and segregation and of the latter plasmid content, growth phase, and ecological conditions. These factors have to be measured with experimental models, and included in mathematical models, to estimate their relative incidence.
\end{abstract}

\section{Introduction}

Numerous experiments have been conducted to determine factors influencing plasmid transfer. In this article attention will be focused on the ecology of Escherichia coli in the gut or in anaerobic continuous flow cultures. A review of the literature distinguishes two types of experiments. In some of them, the potential plasmid donor and recipient bacteria are dominant in the ecosystem while, in others, they are overcome by a predominant flora.

\section{Potential mating bacteria dominating the ecosystem}

Examples of this include batch cultures (broth or agar plate), continuous flow cultures (chemostat) in the absence of other bacteria, germ-free animals (mice, chicken, pigs) dosed with a mating mixture (Sansonetti et al., 1980; Corpet, unpublished results), very young animals (Smith, 1970), humans or animals treated with antibiotics (Datta et al., 1971; Anderson, 1975), and humans or animals with an enteric infection (leading to the dominance of enterobacteria in the gut). In these ecological situations, the transfer of plasmids occurred rapidly and extensively.

\section{Potential mating bacteria sub-dominant in the ecosystem}

Examples of this include continuous flow cultures (with diluted broth, rapid flow rate or brief incubation time (Lebek \& Egger, 1983), or with associated complex ftora), gnotobiotic animals colonized by bacteria (Freter, Freter \& Brickner, 1983; Andremont et al., 1985), and adult humans or animals (Wiedemann, 1972). In these ecological situations, the plasmid transfer is a rare event. This rarity may be due to specific transfer inhibitors synthesized by the anaerobes.

In the systems cited under (I), above, donor and recipient bacteria grow actively and reach high densities, while in ecosystems cited under (II), the concentration of potential mating bacteria is low, and their growth phase is almost static. This raises the question of the different factors involved in plasmid transfer, and their relative importance. The question was studied by Freter et al. (1983), and their approach, both experimental and mathematical, has produced clear answers which are considered below. 
The plasmid transfer, estimated by the number of new conjugants created/unit of time, is directly proportional to the number of recipient and donor bacteria/unit volume, because mating requires the presence of both cells. It depends also on the fertility of the strains, i.e. their success in donating or accepting a plasmid.

The number of recipient bacteria/ml [N] depends on:

(a) The flow rate constant [Ro]

In the digestive tract, the flow rate depends on the animal species, diet and flora (e.g. germfree (axenic) rodents have slow intestinal transit), whereas in a chemostat it is fixed. The flow causes a wash-out of the bacteria, decreasing their number [-Ro x N], and it brings new nutrients to the remaining populations, allowing continuous growth.

(b) The concentration of the limiting substrate [S]

The concentration of substrate that enters the system is fixed in vitro (composition of the broth) but depends partially on the composition of the food in vivo. The limiting substrate is mainly metabolized by the predominant flora (anaerobes), which compete with $E$. coli for nutrients. The resulting concentration of substrate $[\mathrm{Sr}]$ is available for $E$. coli. The flow rate brings fresh material into the system. increasing the substrate concentration [+Ro x $(\mathrm{Sr}-\mathrm{S})]$, whereas the growth of donor and recipient bacteria decreases the substrate concentration. The nature of the limiting substrate in vivo cannot be known, but the numerical value of its concentration can be estimated from the number of bacteria produced in the gut, in relation to the specific yield [Y] of the substrate (the ratio of grains of bacteria produced/grams of substrate used).

\section{(c) Growth rate [Psi]}

The intrinsic characteristics of growth of the dominant strain are the maximum growth rate [Mu] (at optimal concentration of the substrate) and the saturation constant for the limiting substrate [Ks] (which is equal to the substrate concentration which leads to half the maximum growth rate). According to the classical Monod equation, the growth rate is a function of the limiting substrate concentration $[\mathrm{Psi}=\mathrm{Mu} \times \mathrm{S} /(\mathrm{Ks}+\mathrm{S})]$. The growth rate may be lowered by natural inhibitors (bile salts, volatile fatty acids, etc.) or ingested antibiotics. A measurement of the absolute bacterial replication in vivo was proposed by Hooke et al. (1985), by inoculation of the ecosystem with a mixture of thermosensitive mutants and wild type strains, and the measure of their ratio. The growth rate allowing the increase in the number of bacteria [+Psi $\mathrm{x} \mathrm{N}$, correlatively decreases the substrate concentration [-Psi x N/Y].

(d) Adhesion to the wall

Adhesion may be nonspecific; e.g. Cohen et al. (1985) demonstrated adhesion of an E. coli strain of human origin to the mouse colonic mucosa; the adhesive structures were the lipopolysaccharide and a mucosal glycoprotein. Alternatively it may be specific for the strain (e.g. a plasmid governing the synthesis of adhesin). The characteristics of the wall also must play a role and will vary with the animal species and the immune status. Very low levels of antibiotics can inhibit the adhesion of bacteria, without any other detectable effect. Bound bacteria avoid being washed out of the gut.

The number of plasmid donor bacteria/ml [NR] depends on:

\section{(a) Contamination}

The input of donor bacteria in the gut depends on the frequency of contamination and on the density of the inoculum (number of ingested plasmids). For example, Linton et al. (1977) described the contamination of the human gut by resistant E. coli from chicken carcasses. Petrocheilou, Richmond \& Bennett (1977) clearly showed the spread of an R-plasmid from a wife to her husband 
and, according to Datta et al. (1971), resistant E. cnli appearing after antimicrobial therapy were never the original predominant serotype with acquired resistance, neither was there overgrowth of the resistant serotype previously prescrit in small numbers; there was always colonization of the bowel with a new resistant serotype. The quantitative incidence of contamination still remains to be determined in normal life.

(b) Factors which are the same for donor and recipient bacteria The flow rate constant [Ro], the concentration of the limiting substrate [Sr and S], the presence of inhibitors and the structure of the wall are the saine for recipient and donor bacteria but have différent effects in the two populations, because of factors listed below.

(c) Growth rate [PsiR].

According to numerous authors (e.g. Andremont et al., 1985) most R-plasmids have a detrimental effect on the in-vivo growth rates of their hosts bacteria. Some plasmids, however, increase the invivo fitness of the bacterium carrying them, for reasons which are not known. The growth rate of the donor bacteria depends on its maximum growth rate [MuR], on its saturation constant for the limiting substrate [KsR], and on [S]. Antibiotics will not decrease the growth rate of resistant bacteria.

\section{(d) Adhesion of donor bacteria}

Generally, the donor bacterium reaches the gut where plasmid-free bacteria are dominant. Adhesion sites are occupied by the first invader; later ones have few chances to find available sites, unless they have specific adhesion structures, namely type 1 pili, or attachment antigens coded by plasmids (e.g. K99). The production of adhesin is itself a function of growth rate (Van Verseveld et al., 1985). Duval-iflah, Raibaud \& Rousseau (1981) demonstrated a phenotypic adaptive mechanism which occurred in E. coli associated with germ-free mice for al least 30 days, and allowed the adapted bacteria systematically to overcome any non-adapted strain.

\section{(e) Segregation}

The rate of segregation is low and is dependent on the plasmid. Its effect is proportional to the number of plasmid-bearing bacteria that are multiplying, because the loss of plasmid occurs when a bacterium divides into two new cells, one of which is plasmid-free. Segregation, which has no detectable effect in vitro, in the long-term determines equilibrium in vivo.

\section{Specific parameters of the transfer itself}

These factors are included in the concept of fertility which is formalized by the transfer rate constant [Gamma]. It is the intrinsic ability to transfer the plasmid in given conditions (if it was really an intrinsic constant, the conditions should not modify it). The number of new conjugants/unit of time is [+Gamma x N x NR].

\section{(a) Plasmid}

The nature of the plasmid is the most important determinant of the fertility. Some plasmid characteristics are well known, for example, the ability to conjugate (non-conjugative plasmids needing the presence of a conjugative helper plasmid to cotransfer) and the repressed status. In newly formed conjugants, the transfer functions are stimulated, and consequently [Gamma] increases a lot. Most of the in-vivo transfers are in fact due to derepressed new conjugants (Sansonetti et al., 1980). After a certain number of generations, the transfer functions are repressed again, except in permanently derepressed $d r d$ mutants.

\section{(b) Donor and recipient bacteria}


The ability to give and accept a plasmid are characteristics of the mating strains, and depends on their stat.us.

(i) Growth phase. The effect of the static phase of growth was studied in vitro by Levin, Stewart \& Rice (1979) and by Freter et al. (1983) in vivo, injection of morphine to mice strongly reduces their intestinal motility, and consequently Ro. S and Psi. They found that the transfer was severely impaired by static conditions. In particular, there was a strong relationship between the growth rate of the donor bacterium and its fertility. In the gut, the transient potential donor strains are generally prevented from multiplying by the antagonistic effect of the resident microflora. This explains the considerably lower fertility of a strain in the presence of a complex flora than in a test tube or in a sterile gut.

(ii) Wild type smooth strains are less efficient donors and recipients than rough strains. This fact explains the maintenance and spread of non-conjugative plasmids among populations of wildtype E. coli strains in vivo for a long time, because the low intrinsic efficiency for plasmid transfer ensures the presence of a large plasmid-free population which is potentially able to act as recipients to any plasmid.

(iii) Conjugative systems; the con mutation in the recipient bacterium strongly decreases the rate of transfer (Sansonetti et al., 1980).

(iv) The presence of an incompatible plasmid in the potential recipient, because two plasmids of the same incompatibility group are mutually exclusive, or of an enhancer plasmid, e.g. plasmid pBR322 the presence of which in the potential recipient increases the efficacy of transfer (Freter et al., 1983).

\section{(c) Ecological conditions}

Some environmental factors have a proven effect, but it is difficult to know whether they act on the mating strains (population size and growth phase) or on the transfer itself. These factors are the physico-chemical conditions ( $\mathrm{rH}, \mathrm{pH}$, etc.) (Wiedemann, 1972) and the temperature; for example, the thermosensitive $\mathrm{H} 2$ plasmid transfers outside the gut and is then ingested by calves (Timoney \& Linton, 1982). Another factor is the mixing effect of peristaltic movements of the gut, which may separate mating cells. The localization of the bacteria (adhesion to the wall) and their topographical location along the gut may have an effect on mating, if potential donor and recipient cells cannot meet.

Specific interfering substances, which would inhibit the transfer itself, have been invoked frequently but their presence in vivo is still hypothetical. On the other hand, some antibiotics, for example bambermycins (Corpet, 1984), are well known to inhibit the replication or the transfer of plasmids.

\section{Conclusions}

The factors interfering with plasmid transfer are too numerous to be measured simultaneously in vivo. Parameters must be isolated in experimental models, such as continuous flow cultures or gnotobiotic animals.

These factors are too numerous to be comprehended simultaneously, particularly in their quantitative relationships. One has to build a mathematical model to estimate the relative effect of each factor. This was done by Freter et al. (1983), and the differential equations they propose can be used, with and without modifications, to test new hypotheses and to conduct more accurate experiments. The results of computer simulations based on measurements made in experimental models indicate that:

(i) the reduction of growth rate generally observed in plasmid-bearing bacteria explains the general dominance of antibiotic-susceptible bacteria in mammals' digestive tracts; and

(ii) the efficiency of in-vivo plasmid -transfer does not differ from that occurring in vitro. The observed differences (the very low rates of in-vivo plasmid transfer) are referable mainly to the population densities of $E$. coli in the gut of normally reared mammals. 


\section{References}

Anderson, E. S. (1975). Viability of, and transfer of a plasmid from, E. coli K12 in the human intestine. Nature 255, 502-4. Andremont, A., Gerbaud, G., Tancrede, C. \& Courvalin, P. (1985). Plasmid-mediated susceptibility to intestinal microbial antagonisms in E. coli. Infection and Immunity 49, 751-5.

Cohen, P. S., Arruda, J. C., Williams, T. J. \& Laux, D. C. (1985). Adhesion of a human fecal E. coli strain to mouse colonic mucus. Infection and Immunity 48, 139-45.

Corpet, D. E. (1984). The effect of bambermycin, carbadox, chlortetracycline and olaquindox on antibiotic resistance in intestinal coliforms: a new animal model. Ann. Microbiol. (Institut Pasteur) 135A, 329-39.

Datta, N., Faiers, M. C., Reeves, D. S., Brumfitt, W., Orskov, F. \& Orskov, I. (1971). R factors in E. coli in faeces after oral chemotherapy in general practice. Lancet ii, 312-5.

Duval-iflah, Y., Raibaud, P. \& Rousseau, M. (1981). Antagonisms among isogenic strains of E. coli in the digestive tracts of gnotobiotic mice. Infection and Immunity 34, 957-69.

Freter, R., Freter, R. R. \& Brickner, H. (1983). Experimental and mathematical models of E. coli plasmid transfer in vitro and in vivo. Infection and Immunity 39, 60-84.

Hooke, A. M., Sordelli, D. O., Cerquetti, M. C. \& Vogt, A. J. (1985). Quantitative determination of bacterial replication in vivo. Infection and Immunity 49, 424-7.

Lebek, G. \& Egger, R. (1983). R-selection of subbacteriostatic tetracycline concentrations. Zentralblatt für Bakteriologie, Mikrobiologie und Hygiene 1 Abt. Orig. A 255, 340-5.

Levin, B. R., Stewart, F. M. \& Rice, V. A. (1979). The kinetics of conjugative plasmid transmission: fit of a simple mass action model. Plasmid 2, 247-60.

Linton, A. H., Howe, K., Bennett, PM., Richmond, MH. \& Whiteside, E. J. (1977). The colonization of the human gut by antibiotic resistant E. coli from chickens. Journal of Applied Bacteriology 43, 465-9.

Petrocheilou, V., Richmond, M. H. \& Bennet, P. M. (1977). Spread of a single plasmid from a person receiving prolonged tetracycline therapy. Antimicrobial Agents and Chemotherapy 12, 219-25.

Sansonetti, P., Lafont, J. P., Jaffe-Brachet, K., Guillot, J. F. \& Chaslus-Dancla, E. (1980). Parameters controlling interbacterial plasmid spreading in a gnotoxenic chicken gut system, influence of plasmid and bacterial mutations. Antimicrobial Agents and Chemotherapy 17, 327-33.

Smith, H. W. (1970). The transfer of antibiotic resistance between strains of enterobacteria in chicken, calves and pigs. Journal of Medical Microbiology 3, 165-80.

Timoney, J. F. \& Linton, A. H. (1982). Experimental ecological studies on H2 plasmids in the intestine and faeces of the calf. Journal of Applied Bacteriology 52, 417-24.

Van Verseveld, H. W., Bakker, P., Van der Woude, T., Terleth, C. \& de Graaf, F. K. (1985). Production of fimbrial adhesins K99 and F41 by enterotoxigenic E. coli as a function of growth rate domain. Infection and Immunity 49, 159-63.

Wiedemann, B. (1972). Die Uebertragung extrachromosomaler Resistenzfaktoren in der Darmflora und ihre Hemmung. Zentralblatt für Bakt., Paras. Infek. Hyg. Abt. 1 Orig. 220, 106-23. 